\title{
PENGARUH PERSEPSI TENTANG ADVERTORIAL PRODUK KESEHATAN DI KORAN PADA SIKAP KONSUMEN
}

\author{
Rika Melati* \\ *Fakultas Farmasi, Universitas Nadhlatul Ulama Kalimantan Timur
}

\begin{abstract}
Advertorial is advertising looks like news as its editorial format. The purpose of advertising is to influence consumer buying behavior. Consumer attitude is one of predictor to determine consumer behavior. The purpose of this research is to analysis influence perception of health product advertorial toward consumer attitude. Method of this research is survey which Gadjah Mada University (GMU) student that have read advertorial of healt product in newspaper as population. Method of sampling use purposive sampling. There are 3 variables in this research: perception of health product advertorial as independent variable while cognitive and affective response as dependent variables. All variables are measured using Likert scale. The primary data collected using questionnaires that given to 170 respondents. Validity and reliability of research instrument were tested using Confirmatory Factor Analysis and Alpha Cronbach's. All hypotheses tested by using Linear Regression. The finding of this research shown that perception of health product advertorial significantly influence cognitive and affective of consumer response. The influence perception of health product advertorial toward cognitive response of GMU student that read newpaper is $21,3 \%$ and the influence of health product advertorial toward affective response of GMU student that read newspaper is $8,7 \%$. Another factors estimated influencing attitude toward the advertorial are individual education, attitude toward the brand previously, and level of individual involvement.
\end{abstract}

Keyword: Advertorial, attitude, perception

DOI: https://doi.org/10.25026/jsk.v1i10.91

PENDAHULUAN

Advertorial menjadi salah satu pilihan iklan yang marak digunakan saat ini baik secara online maupun media cetak. Menurut Dorbian (2009) sebesar $67 \%$ anak muda Amerika dengan usia berkisar antara 18-24 tahun sangat menggemari membaca advertorial, dan $51 \%$ penduduk Amerika lebih memilih membaca advertorial dibandingkan dengan iklan merek, pop-ups, dan penawaran lewat email. Penelitian mengenai efektivitas advertorial oleh

Schlossberg dan Canter (2007)
menunjukkan bahwa advertorial
seharusnya dipertimbangkan sebagai
salah satu bagian dalam media mix,
terutama sebagai pesan tambahan dengan
topik edukasi. Pembaca akan
menunjukkan perhatian yang lebih
terhadap format yang dirasa lebih editorial
dibandingkan dengan pesan komersial
(Cameron dkk., 1996; Van Reijmersdal
dkk., 2005).
Konsumen yang dimaksud dalam
penelitian ini adalah pembaca advertorial


produk kesehatan di koran. Sebagian besar pembaca advertorial berusia antara 18-24 tahun (Dorbian, 2009). Rentang usia tersebut merupakan rentang usia sebagian besar mahasiswa.

\section{Advertorial.}

Menurut Kotler dan Keller (2006, hal. 536) advertorial merupakan iklan cetak yang menawarkan isi editorial yang mencerminkan hal-hal baik mengenai merek dan sulit dibedakan dengan isi majalah atau koran. Namun seiring perkembangan zaman, advertorial tidak hanya dimuat pada iklan cetak namun juga dimuat secara online melalui internet (Dorbian, 2009). Untuk memperoleh ekspose ganda, advertorial dapat digunakan untuk mengangkat isu yang berbeda di samping isu yang ditampilkan pada iklan tradisional. Advertorial dapat menjadi lebih efektif dibandingkan dengan iklan tradisional apabila pembaca membacanya dengan baik. Pesan advertorial dapat bertahan lebih lama berada dalam ingatan pembaca dibandingkan pesan komersial. Karena ada keragu-raguan pembaca saat menerima pesan komersial (Dorbian, 2009; Cameron, dkk., 1996).

\section{Perilaku Konsumen.}

Menurut Schiffman and Kanuk (2000, hal. 6) perilaku konsumen adalah proses yang dilalui oleh seseorang dalam mencari, membeli, menggunakan, mengevaluasi, dan bertindak paska konsumsi produk, jasa, maupun ide yang diharapkan bisa memenuhi kebutuhannya. Untuk melaksanakan semua kegiatan dalam proses manajemen pemasaran, pemasar perlu mengetahui perilaku konsumen. Sasarannya supaya kiat-kiat pemasaran yang dilakukkan benar-benar mengarah pada profitabilitas dari perusahaan. Singkatnya perilaku konsumen dipelajari agar lebih memahami tentang apa yang dibeli oleh konsumen, mengapa, dimana, kapan, dan seberapa sering dia membeli. Pengetahuan ini kemudian dipakai untuk menciptakan cara untuk memuaskan/memenuhi kebutuhan mereka dan menciptakan pendekatan yang baik untuk berkomunikasi dan mempengaruhi mereka (Prasetijo dan Ihalauw, 2005, hal. 11-12).

Menurut Schiffman dan Kanuk (2000, hal. 273-275) salah satu model pendekatan terhadap sikap yaitu Tricomponent Attitude Model. Model ini memandang sikap terdiri dari 3 komponen, yaitu:

1. Komponen kognitif yaitu: pengetahuan (cognition) dan persepsi yang diperoleh melalui kombinasi dari pengalaman dengan objek sikap dan informasi terkait yang didapat dari berbagai sumber.

2. Komponen afektif yaitu: emosi atau perasaan terhadap suatu produk atau merek tertentu. Emosi atau perasaan terutama memiliki hakikat evaluatif yaitu apakah konsumen suka atau tidak terhadap produk tertentu.

3. Komponen konatif yaitu: kecenderungan seseorang untuk melaksanakan suatu tindakan dan perilaku dengan cara tertentu terhadap suatu objek sikap.

Ketiga komponen ini cenderung untuk konsisten namun tidak permanen. Perubahan salah satu komponen dalam sikap akan selalu diikuti oleh perubahan komponen-komponen yang lain.

Pada penelitian ini dilakukan pengukuran respon kognitif dan afektif konsumen terhadap advertorial. Menurut Teng dkk. (2007) respon kognitif dan afektif konsumen merupakan penentu evaluasi pada iklan. Respon kognitif dan afektif merupakan dua hal berbeda, namun keduanya tidak dapat dipisahkan. Respon kognitif merupakan hasil dari proses kesadaran terhadap elemen spesifik pada 
iklan serta ide dan pikiran konsumen yang ditimbulkan oleh pesan persuasif iklan. Pembentukan respon kognitif sangat menentukan pada proses perubahan sikap. Selanjutnya induksi pada reaksi afektif secara menyeluruh akan mentransfer perubahan sikap terhadap iklan.

\section{METODE PENELITIAN}

Penelitian ini merupakan penelitian non eksperimental menggunakan metode survei dengan memberikan kuesioner kepada responden untuk tujuan pengujian hipotesis.

Dalam penelitian ini populasi yang dimaksud adalah Mahasiswa UGM yang membaca koran. Mahasiswa UGM pembaca koran dalam penelitian ini dianggap calon konsumen yang menjadi sasaran pengiklan. Sampel dalam penelitian ini adalah sebagian dari populasi tersebut yang digunakan sebagai responden.

Metode pengambilan sampel dilakukan dengan menggunakan metode purposive sampling. Ukuran sampel dalam penelitian ini mengacu pada Roscoe (1975) dalam Sekaran (2006b, hal. 160) bahwa aturan dalam penelitian multivariat, ukuran sampel sebaiknya beberapa kali (lebih disukai 10 kali atau lebih) dari jumlah variabel dalam studi. Pada penelitian ini variabel advertorial, kognitif, dan afektif diukur menggunakan kuesioner dan dijabarkan dalam 17 pertanyaan, sehingga ukuran sampel dalam penelitian ini sebanyak 170 responden.

Variabel-variabel yang digunakan dalam penelitian adalah: (1) Advertorial sebagai variabel bebas (independent variable) sedangkan (2) Respon kognitif mahasiswa pembaca koran di UGM dan (3) Respon afektif mahasiswa pembaca koran di UGM sebagai variabel tergantung (dependent variable). Definisi operasional dari masing-masing variabel tersebut adalah:

\section{Advertorial.}

Dalam penelitian ini advertorial yang dimaksud adalah advertorial produk kesehatan meliputi advertorial produk obat, suplemen, atau kosmetik. Pertanyaan pada kuesioner merupakan pertanyaan tertutup (closed questions) dan diukur menggunakan skala Likert dengan skor : (1) Sangat tidak setuju; (2) Tidak Setuju; (3) Netral; (4) Setuju dan (5) Sangat Setuju. Pertanyaan seputar advertorial mengacu teori advertorial yang dikemukakan oleh Cameron dkk. (1996) meliputi: alasan advertorial tersebut dimuat, tidak bias/menyimpang, mengandung kepentingan yang sedikit, menggunakan berita yang padat, berita utama yang tidak persuasif, sumber informasi yang terpercaya, kehadiran nama sponsor, dan kredibilitas produk yang dimuat.

\section{Respon Kognitif dan Afektif Mahasiswa Pembaca Koran di UGM.}

Secara sederhana kognitif merupakan pengetahuan (knowledge) atau memikirkan (think) sedangkan afektif merupakan perasaan (feeling). Respon kognitif responden diukur menggunakan 6 item pertanyaan yang meliputi: perhatian, ketertarikan, kebenaran informasi, kemampuan mengingat pesan, dan keyakinan pada advertorial (Hausknecht dkk., 1991). Respon afektif responden diukur menggunakan 4 item pertanyaan yang meliputi suka (likely) dan preferensi/lebih suka pada advertorial (Schiffman dan Kanuk, 2000, hal. 270).

Pertanyaan pada kuesioner merupakan pertanyaan tertutup (closed questions) dan diukur menggunakan skala Likert dengan skor : (1) Sangat tidak setuju; (2) Tidak Setuju; (3) Netral; (4) Setuju dan (5) Sangat Setuju. 


\section{Uji Instrumen.}

Sebelum daftar pertanyaan digunakan, terlebih dahulu daftar pertanyaan tersebut diuji validitas dan reliabilitasnya. Pengujian ini dimaksudkan untuk meyakinkan bahwa daftar pertanyaan tersebut dapat digunakan sebagai alat ukur dengan ketepatan pengukuran (goodness of measure) (Sekaran, 2006b, hal. 45).

\section{Validitas.}

Jenis validitas yang digunakan adalah validitas isi dan validitas konstruk. Validitas isi (content validity) merupakan fungsi seberapa baik dimensi dan elemen sebuah konsep telah digambarkan (Sekaran, 2006b, hal. 43) sedangkan validitas konstruk (construct validity) menunjukkan seberapa baik hasil yang diperoleh dari penggunaan pengukuran yang sesuai dengan teori dimana tes dirancang (Sekaran, 2006a, hal. 230). Pengujian validitas menggunakan metode Confirmatory Factor Analysis (CFA).

\section{Reliabilitas.}

Uji reliabilitas alat ukur menggunakan metode Koefisien Alfa Cronbach.

\section{Uji Validitas dan Reliabilitas dengan Sampel Kecil.}

Pada tahap pra penelitian, validitas dan reliabilitas instrumen diujikan pada 40 responden. Analisis CFA menggunakan uji Kaiser-Meyer Olkin (KMO) dan Barlett's Test. Hasil koefisien KMO yang diperoleh 0,632 menunjukkan variabelvariabel telah layak untuk diterapkan analisis faktor. Signifikansi Bartlett's test $0,00 \quad(<0,05)$ mengindikasikan ada korelasi yang cukup antara variabel untuk dapat diproses (Hair dkk., 2006, hal. 115). Proses selanjutnya adalah melihat tabel Anti-image Matrics, untuk menentukan variabel mana saja yang layak digunakan dalam analisis lanjutan. Nilai MSA lebih dari 0,50 menunjukkan variabel layak untuk dianalisis (Andi, 2009, hal. 255; Hair dkk., 2006, hal. 103). Dari hasil analisis diperoleh 3 variabel dengan nilai MSA kurang dari 0,50 yaitu variabel advertorial 2, advertorial 4, dan advertorial 6 dengan nilai MSA berturutturut $0,489,0,258$, dan 0,338 .

Selanjutnya dilakukan uji reliabilitas. Hasil uji reliabilitas pada tiap variabel disajikan pada Tabel 2.

Tabel 1 Hasil uji validitas pada 40 responden menggunakan KMO dan Bartlett' Test KMO and Bartlett's Test

\begin{tabular}{|ll|r|}
\hline $\begin{array}{l}\text { Kaiser-Meyer-Olkin Measure of Sampling } \\
\text { Adequacy. }\end{array}$ & .632 \\
& & \\
Bartlett's Test of & Approx. Chi-Square & 315.111 \\
Sphericity & $\mathrm{df}$ & 136 \\
& Sig. & .000 \\
\hline
\end{tabular}

Tabel 2 Hasil uji reliabilitas tiap variabel menggunakan Alpha Cronbach

\begin{tabular}{ccc}
\hline No. & Variabel & Koefisien Alpha Cronbach \\
\hline 1 & Advertorial & 0,384 \\
2 & Kognitif & 0,704 \\
3 & Afektif & 0,662 \\
\hline
\end{tabular}


Tabel 3 Hasil uji validitas menggunakan KMO dan Bartlett' Test pada 170 responden

KMO and Bartlett's Test

\begin{tabular}{|c|c|c|}
\hline \multicolumn{2}{|c|}{$\begin{array}{l}\text { Kaiser-Meyer-Olkin Measure of Sampling } \\
\text { Adequacy. }\end{array}$} & .877 \\
\hline $\begin{array}{l}\text { Bartlett's Test of } \\
\text { Sphericity }\end{array}$ & $\begin{array}{l}\text { Approx. Chi-Square } \\
\text { df } \\
\text { Sig. }\end{array}$ & $\begin{array}{r}1064.440 \\
136 \\
.000\end{array}$ \\
\hline
\end{tabular}

Tabel 4 Hasil uji validitas menggunakan KMO dan Bartlett' Test pada variabel kognitif dan afektif

KMO and Bartlett's Test

\begin{tabular}{|c|c|c|}
\hline \multicolumn{2}{|c|}{$\begin{array}{l}\text { Kaiser-Meyer-Olkin Measure of Sampling } \\
\text { Adequacy. }\end{array}$} & .863 \\
\hline $\begin{array}{l}\text { Bartlett's Test of } \\
\text { Sphericity }\end{array}$ & $\begin{array}{l}\text { Approx. Chi-Square } \\
\text { df } \\
\text { Sig. }\end{array}$ & $\begin{array}{r}758.882 \\
45 \\
.000\end{array}$ \\
\hline
\end{tabular}

Tabel 5. Status validitas tiap item pertanyaan

\begin{tabular}{ll}
\hline Item pertanyaan & $\begin{array}{l}\text { Status } \\
\text { Validitas }\end{array}$ \\
\hline Advertorial 1 & Invalid \\
Advertorial 2 & Invalid \\
Advertorial 3 & Invalid \\
Advertorial 4 & Valid \\
Advertorial 5 & Valid \\
Advertorial 6 & Valid \\
Advertorial 7 & Valid \\
Kognitif 1 & Invalid \\
Kognitif2 & Invalid \\
Kognitif3 & Invalid \\
Kognitif 4 & Valid \\
Kognitif 5 & Valid \\
Kognitif 6 & Valid \\
Afektif 1 & Valid \\
Afektif 2 & Valid \\
Afektif 3 & Valid \\
Afektif 4 & Invalid \\
\hline
\end{tabular}


Tahap penerimaan dianggap reliabel apabila nilai Koefisien Alpha Cronbach di atas 0,60 (Van Reijmersdal dkk., 2005; Hair dkk., 2006, hal. 778). Hasil analisis data menunjukkan nilai Koefisien Alpha Cronbach pada variabel advertorial sebesar 0,384 sedangkan nilai Koefisien Alpha Cronbach variabel kognitif dan afektif berturut-turut adalah 0,704 dan 0,662 . Pada variabel advertorial diperoleh nilai koefisien Alpha Cronbach yang kecil, seperti yang telah dikemukakan sebelumnya bahwa ukuran sampel yang kecil kemungkinan menjadi penyebab hasil yang diperoleh kurang baik.

Pada penelitian selanjutnya dilakukan uji validitas dan reliabilitas dengan ukuran sampel besar dan tetap memasukkan item pertanyaan advertorial 2 , 4, dan 6. Hasil uji validitas dengan nilai KMO MSA <0,50 diperkirakan karena ukuran sampel terbatas yakni sebanyak 40 responden. Analisis faktor sebaiknya menggunakan ukuran sampel tidak kurang dari 50 dan akan lebih baik jika sampel berjumlah 100 atau lebih (Hair dkk., 2006, hal. 112). Selanjutnya validitas dan reliabilitas kuesioner diujikan pada seluruh sampel sebanyak 170 responden.

Teknik Pengolahan Data.

Analisis data yang dilakukan dalam penelitian ini meliputi analisis deskriptif dan analisis kuantitatif atau statistika. Analisis statistika menggunakan uji Regresi Linier berdasarkan koefisien regresi, nilai t hitung, dan nilai $\mathrm{p}$ yang dibandingkan dengan $\alpha$.

\section{HASIL DAN PEMBAHASAN}

\section{Uji Validitas dan Reliabilitas dengan Sampel Besar.}

Uji validitas dan reliabilitas diujikan pada 170 data yang telah dikumpulkan. Hasil analisis menunjukkan
Signifikansi Bartlett's test $0,00 \quad(<0,05)$ (lihat Tabel 6.3) mengindikasikan ada korelasi yang cukup antara variabel untuk dapat diproses (Hair dkk., 2006, hal.115). Hasil uji CFA berdasarkan nilai koefisien KMO sebesar 0,877 (lihat Tabel 3). Semakin tinggi nilai KMO semakin valid suatu instrumen. Hasil koefisien KMO yang diperoleh 0,877 menunjukkan kuesioner dapat digunakan sebagai alat ukur. Nilai MSA masing-masing item pertanyaan > 0,5. Nilai MSA lebih dari 0,50 menunjukkan variabel layak untuk dianalisis selanjutnya (Andi, 2009, hal. 255; Hair dkk., 2006, hal. 103).

Tahap selanjutnya adalah dengan merotasi semua item pertanyaan menggunakan rotasi varimax untuk melihat apakah variabel-variabel tersebut telah berkelompok sesuai dengan yang diinginkan. Dalam validitas konstruk, nilai factor loading harus 0,5 atau lebih (Andi, 2003, hal.191; Hair dkk., 2006, hal. 779).

Oleh sebab sebagian besar item pertanyaan yang mewakili variabel kognitif dan afektif mengumpul pada faktor yang sama, selanjutnya dilakukan uji CFA kembali pada variabel kognitif dan afektif tanpa memasukkan variabel advertorial. Hasil uji CFA berdasarkan nilai koefisien KMO sebesar 0,836 (lihat Tabel 4) dan nilai MSA item pertanyaan yang mewakili variabel kognitif dan afektif lebih dari 0,5 .

Berdasarkan nilai factor loading hasil rotasi, maka item-item pertanyaan variabel kognitif yang memiliki factor loading besar pada faktor 2 diinterpretasikan valid sedangkan itemitem pertanyaan variabel afektif yang memiliki factor loading besar pada faktor 1 diinterpretasikan valid. Status validitas tiap item pertanyaan dari hasil uji CFA pada variabel advertorial, kognitif, dan afektif maupun pada uji CFA dengan 
hanya menggunakan variabel kognitif dan afektif disajikan pada Tabel 5.

Pada analisis selanjutnya, itemitem pertanyaan yang dinyatakan tidak valid akan dikeluarkan dari instrumen penelitian dan tidak diikutsertakan pada uji reliabilitas dan pengujian hipotesis. Nilai Koefisien Alpha Cronbach di atas 0,60 diinterpretasikan bahwa instrumen dalam penelitian reliabel (Van Reijmersdal dkk., 2005; Hair dkk., 2006, hal. 778). Nilai Koefisien Alpha Cronbach pada variabel advertorial, respon kognitif, dan respon afektif adalah 0,624, 0,679, dan 0,752 sehingga instrumen dalam penelitian ini diinterpretasikan reliabel.

\section{Pengaruh Advertorial pada Respon Kognitif}

Perhitungan regresi dilakukan dengan program SPSS 12.00 for Windows. Tabel 6 adalah ringkasan hasil perhitungan regresi antara variabel advertorial dengan variabel respon kognitif.

Nilai R Square sebesar 0,213 menunjukkan pengaruh advertorial produk kesehatan yang dapat menjelaskan respon kognitif mahasiswa pembaca koran atau advertorial produk kesehatan mempengaruhi respon kognitif mahasiswa pembaca koran sebesar sebesar 21,3\%, sedangkan sisanya 78,7\% dijelaskan oleh variabel-variabel lain yang tidak terdapat dalam persamaan regresi. Angka R Square berkisar antara 0 sampai 1 , semakin kecil angka R Square maka akan semakin lemah hubungan kedua variabel (Santoso, 2004, hal. 318). Pada hasil penelitian menunjukkan angka $\mathrm{R}$ Square yang relatif kecil. Hal ini kemungkinan ada faktor lain di samping advertorial produk kesehatan, yang mempengaruhi respon kognitif responden.

Nilai beta yang diperoleh sebesar 0,461. Nilai beta yang positif menunjukkan pengaruh positif advertorial produk kesehatan pada respon kognitif mahasiswa pembaca koran. Hal ini mengindikasikan bahwa semakin sering mahasiswa UGM membaca advertorial produk kesehatan di koran makan respon kognitif yang diperoleh akan semakin besar.

Hasil analisis regresi antara advertorial dengan respon kognitif mahasiswa pembaca koran menunjukkan nilai signifikasi 0,000 lebih kecil dari $\alpha=$ 0,05 yang berarti $\mathrm{p}<\alpha$. Hasil analisis regresi menunjukkan bahwa pada tingkat kepercayaan 95\%, advertorial berpengaruh secara signifikan pada respon kognitif.

Tabel 6 Ringkasan hasil analisis regresi pengaruh advertorial pada respon kognitif mahasiswa pembaca koran

\begin{tabular}{llllllll}
\hline $\begin{array}{l}\text { Variabel } \\
\text { dependen }\end{array}$ & $\begin{array}{l}\text { Variabel } \\
\text { independen }\end{array}$ & Konstanta & $\begin{array}{l}\text { Koefisien } \\
(\mathrm{B})\end{array}$ & beta & $\begin{array}{l}\mathrm{t} \\
\text { hitung }\end{array}$ & $\begin{array}{l}\text { Signifikasi } \\
(\mathrm{p})\end{array}$ & $\begin{array}{l}\mathrm{R} \\
\text { Square }\end{array}$ \\
\hline $\begin{array}{l}\text { Respon } \\
\text { kognitif }\end{array}$ & Advertorial & 3,879 & 0,429 & & 6,739 & 0,000 & 0,213 \\
\hline
\end{tabular}

Tabel 7 Ringkasan hasil analisis regresi pengaruh advertorial pada respon afektif mahasiswa pembaca koran

\begin{tabular}{llllllll}
\hline $\begin{array}{l}\text { Variabel } \\
\text { dependen }\end{array}$ & $\begin{array}{l}\text { Variabel } \\
\text { independen }\end{array}$ & Konstanta & $\begin{array}{l}\text { Koefisien } \\
(\mathrm{B})\end{array}$ & Beta & $\begin{array}{c}\mathrm{t} \\
\text { hitung }\end{array}$ & $\begin{array}{l}\text { Signifikansi } \\
(\mathrm{p})\end{array}$ & $\begin{array}{l}\mathrm{R} \\
\text { Square }\end{array}$ \\
\hline $\begin{array}{l}\text { Respon } \\
\text { afektif }\end{array}$ & Advertorial & 0,822 & ) 0,293 & 0,294 & 3,992 & 0,000 & 0,087 \\
\hline
\end{tabular}




\section{Pengaruh Advertorial pada Respon Afektif.}

Nilai R Square yang diperoleh sebesar 0,087. Nilai ini menunjukkan kemampuan variabel independen menjelaskan variabel dependen.

Pada regresi sederhana, angka beta (koefisien standar) adalah angka koefisien korelasi (R). Nilai beta yang diperoleh sebesar 0,294. Nilai beta yang positif menunjukkan pengaruh positif advertorial produk kesehatan pada respon afektifif mahasiswa pembaca koran. Hal ini mengindikasikan bahwa semakin sering mahasiswa UGM membaca advertorial produk kesehatan di koran makan respon afektif yang diperoleh akan semakin besar.

Analisis regresi antara advertorial dengan respon afektif menunjukkan nilai signifikasi 0,000 lebih kecil dari $\alpha=0,05$ yang berarti bahwa $\mathrm{p}<\alpha$. Hasil analisis regresi menunjukkan bahwa pada tingkat kepercayaan 95\%, advertorial berpengaruh secara signifikan pada respon afektif mahasiswa pembaca koran

\section{KESIMPULAN}

1. Advertorial produk kesehatan berpengaruh positif pada respon kognitif mahasiswa pembaca koran di Universitas Gadjah Mada.

2. Advertorial produk kesehatan berpengaruh positif pada respon afektif mahasiswa pembaca koran di Universitas Gadjah Mada.

3. Respon kognitif dan afektif yang positif menandakan sikap mahasiswa pembaca koran yang positif pada advertorial produk kesehatan.

\section{DAFTAR PUSTAKA}

Cameron, G.T; Ju-Pak, K; dan Kim, B. (1996), "Advertorials in Magazines: Current Use and Compliance With Industry Guidelines," Journalism and Mass Communication Quarterly, Vol. 73, No. 3, 722-733.

Dorbian, I. (2009), "Your Article Here: The Endless Advertorial Debate," Min's B2B, June 22, 2009.

Hair, J.F; Black, W.C; Babin, B.J; Enderson,R.E; dan Tatham, R.L. (2006), Mutivariate Data Analysis, $5^{\text {th }}$ ed, Upper Saddle River: Pearson Education.

Hausknecht, D.R; Wilkinson, J.B; dan Prough, G.E. (1991), “Advertorial: Effective? Deceptive? Or Tempest in a Teapot?," Akron Economic and Bussiness Review, Vol. 22, No. 4, 41-52.

Kotler, P. dan Keller, K. (2007a), Manajemen Pemasaran, edisi 12 Jilid 1, Jakarta: Penerbit Indeks.

Kotler, P. dan Keller, K. (2007b), Manajemen Pemasaran, edisi 12 Jilid 2, Jakarta: Penerbit Indeks.

Muehling, D.D. dan McCann, M. (1993), "Attitude Toward the Ad: A Review," Journal of Current Issues and Research in Advertising, Vol. 15 No. 2, 25-58.

Peter, J. dan Olson J.C. (2000), Consumer Behavior, edisi 4 Jilid 2, Jakarta: Penerbit Erlangga.

Prounis, C. (2004), "The Art of Advertorial," Pharmaceutical Executive, Vol. 24, No. 5, 152164.

Sekaran, U. (2006a), Metode Penelitian Untuk Bisnis, edisi 4 Jilid 1, Jakarta: Penerbit Salemba Empat. 
Sekaran, U. (2006b), Metode Penelitian Untuk Bisnis, edisi 4 Jilid 2, Jakarta: Penerbit Salemba Empat. Schiffman, L.G. dan Kanuk L.K. (2000), Consumer Behaviour, $7^{\text {th }}$ ed, Upper Saddle River: Pearson Education.

Schlossberg, J. dan Canter, G. (2007), "The Advertorial Effect", Pharmaceutical Executive, Vol. 27, No. 6, 104-106.

Teng, L; Laroche, M; dan Zhu, H. (2007), "The Effects of Multiple-ads and Multiple-brands On Consumer Attitude and Purchase Behavior," Journal of Consumer Marketing, Vol. 24, No.1, 27-35.
Van Reijmersdal, E; Neijens, P; dan Smit, E. (2005), "Readers' Reactions to Mixtures of Advertising and Editorial Content in Magazines," Journal of Current Issues and Research in Advertising, Vol. 27, No. 2, 40-53.

Yi, Y. (1990), "Cognitive and Affective Priming Effects of the Context for Print Advertisements," Journal of Advertising, Vol. 19, No. 2. 40-48. 